\title{
SAUS: A tool for preserving urban green areas from air pollution
}

\author{
Lígia T. Silva*, Fernando Fonseca, Maria Pires, Bruno Mendes \\ CTAC - Centre for Territory, Environment and Construction. University of Minho. Braga, Portugal
}

\section{A R T I C L E I N F O}

Handling Editor: Cecil Konijnendijk van den Bosch

Keywords:

Preserving

Preventive planning

Urban air pollution

Urban green areas

\begin{abstract}
A B S T R A C T
Urban spaces are increasingly exposed to air pollution, which critically influences the health and well-being of cities' inhabitants. Urban green areas provide recognised important environmental and social functions. Providing, planning, managing, and protecting urban green areas are on the agenda of sustainability and liveability of cities. In this paper, urban green areas are classified as Sensitive Areas in Urban Spaces (SAUS), corresponding to critical environmental and social spaces that should be preserved from surrounding air pollution sources. The concept of SAUS was tested in two urban green areas of Guimarães, a medium-sized Portuguese city, by defining a buffer of $300 \mathrm{~m}(\mathrm{~m})$ around each area. Industrial plants and traffic were the sources of air pollution analysed by considering their emissions of NOx, PM10 and $\mathrm{SO}_{2}$. Horizontal maps of NOx, $\mathrm{PM}_{10}$ and $\mathrm{SO}_{2}$ were produced by using the model AUSTAL2000. Results showed that more than $97 \%$ of the SAUS had concentrations equal to or below $5 \mu \mathrm{g} / \mathrm{m}^{3}$ of $\mathrm{NOx}, 0.5 \mu \mathrm{g} / \mathrm{m}^{3}$ of $\mathrm{PM}_{10}$ and $0.1 \mu \mathrm{g} / \mathrm{m}^{3}$ of $\mathrm{SO}_{2}$. Besides the globally low levels of emissions, the sources located in the two buffers had environmental impacts and affected the quality of the air at both SAUS. As the proposed concept was useful for identifying the main air pollution sources and their impact on the air quality of urban green areas, the concept of SAUS could be helpful for support the adoption of planning actions towards improving the sustainability of these areas and maximising their environmental and social benefits. However, more applications are needed for confirming the efficiency of this concept to improve the air quality of urban green areas.
\end{abstract}

\section{Introduction}

Air pollution is considered the most hazardous environmental type of pollution in urban spaces (Zannin et al., 2006). Common urban air pollutants include carbon monoxide (CO), nitrogen dioxide $\left(\mathrm{NO}_{2}\right)$, ozone $\left(\mathrm{O}_{3}\right)$, sulfur dioxide $\left(\mathrm{SO}_{2}\right)$ and particulate matter including $\mathrm{PM}_{2.5}$ and $\mathrm{PM}_{10}$. Pollutants released to the atmosphere by human activities are causing a significant decline in the air quality having serious impacts on health including premature mortality and morbidity from cardiovascular and respiratory causes (Selmi et al., 2016). In Portugal, in 2012 and according to the EEA (2014), a significant fraction of the urban population $(15.7 \%)$ was exposed to $\mathrm{PM}_{10}$ concentrations above the EU daily limit value $\left(50 \mu \mathrm{g} / \mathrm{m}^{3}\right)$. Moreover, the $\mathrm{NO}_{2}$ values recently measured in the largest Portuguese cities namely in Lisbon $\left(57 \mu \mathrm{g} / \mathrm{m}^{3}\right)$, Porto $\left(74.8 \mu \mathrm{g} / \mathrm{m}^{3}\right)$ and Braga $\left(55.3 \mu \mathrm{g} / \mathrm{m}^{3}\right)$ are above the daily limit defined by the EU rules $\left(40 \mu \mathrm{g} / \mathrm{m}^{3}\right)$. A recent study also shows that air pollution is causing about 6600 premature deaths annually in these Portuguese cities (EEA, 2014). Besides the effects on health and the environment, air pollution also has a negative impact on the built environment. Deposition of atmospheric pollutants on surfaces is one of the most important deterioration phenomenon that affects historical building facades and monuments (Slezakova et al., 2011).

In an increasingly urbanised world, urban green areas are important for improving sustainability and citizens' well-being. Urban green areas may have different characteristics in terms of size, vegetation cover, environmental quality, facilities and services provided (Wolch et al., 2014). Urban green areas are generally described as the sum of all the green spaces within a city, including formal open spaces with paved surfaces, gardens, sport grounds, burial places that are directly provided for users and informal green areas comprising urban forests, private gardens, road verges, horticulture, derelict land, etc. (Haq, 2011; Galeeva et al., 2014; Kabisch et al., 2016). Some researchers also use the term "green infrastructure" to denote urban green space (Schäffler and Swilling, 2013). In this current work, the authors used the concept of urban green areas proposed by Contesse et al. (2017) as public goods that allow free access and represent pockets of nature for all residents and that are generally maintained by public agencies for citizens' leisure and recreation.

The overall benefits of urban green areas are discussed in depth in the literature. Environmentally, green areas help to regulate the urban climate (Depietri et al., 2013; Oliveira et al., 2014), namely by creating a cooling effect through evapotranspiration and shade (Fonseca et al.,

\footnotetext{
* Corresponding author.

E-mail address: 1silva@civil.uminho.pt (L.T. Silva).
} 
2010; Depietri et al., 2013; Jaganmohan et al., 2016; Nowak et al., 2017) that reduces the urban heat island effect (Cohen et al., 2012; Coppel and Wüstemann, 2017). Therefore, green areas equilibrate the thermal balance (Fintikakis et al., 2011) and the energy consumption in cities (Oliveira et al., 2014; Gupta et al., 2016). By reducing the thermal balance and by their role in carbon sequestration, urban green areas have an important role in climate change mitigation, namely in attenuating the estimated increase in temperatures and heat waves in the hottest seasons (Depietri et al., 2013; Selmi et al., 2016; Kanniah, 2017). Leaf stomata also provide important air-filtering functions by removing some gases (Nowak et al., 2017) and by absorbing and retaining particles on plant surfaces (Schäffler and Swilling, 2013; Nowak et al., 2017). For instance, Selmi et al. (2016) conclude that the trees planted in Strasbourg remove $7 \%$ of the $\mathrm{PM}_{10}$ in the city. Urban green areas also perform a well-documented reduction noise function, providing other positive soundscape experiences (Fang and Ling, 2005; Van Renterghem et al., 2012; Liu et al., 2017). Moreover, they provide habitats to different species and increase biodiversity in cities (Sanches and Pellegrino, 2016; Contesse et al., 2017; Kanniah, 2017). They also have a positive role in minimising flooding, erosion and silting up (Sanches and Pellegrino, 2016). As urban green areas provide attractive environments to residents, they perform a social function (Dzhambov and Dimitrova, 2015). According to Zhou and Rana (2012), urban green areas provide recreational opportunities, render aesthetic enjoyment, promote physical health, improve psychological well-being, enhance social ties and provide educational opportunities. While serving as public and open outdoors spaces, they foster social interactions and integration (Gupta et al., 2016; Rojas et al., 2016) and consequently contribute to reducing loneliness and increasing the sense of community (Donovan, 2017). From the economic point of view, researchers agree that increasing the tree canopy cover in the vicinity of a property raises its value (Bertram and Rehdanz, 2015; Li et al., 2015). There are other economic benefits which are more difficult to estimate, including savings in terms of medical assistance and energy consumption resulting from the proximity to urban green areas (Fonseca et al., 2010).

Due to the multiple benefits, people worldwide have a positive perception about the environmental role played by urban green areas (Fonseca et al., 2010; Oliveira et al., 2014; Dzhambov and Dimitrova, 2015; Lo et al., 2017). Moreover, they are described by some authors as "an oasis in the city" (Zhou and Rana, 2012:175) and as a "green lung and nature-conservation companion of the city" (Tian et al., 2014:98). However, vegetation may also cause less favourable effects on the urban environment. For example, vegetation reduces air ventilation that is responsible for distributing and diluting pollutants in the urban atmospheric boundary layer (Vos et al., 2013; Janhäll, 2015; Daniels et al., 2018). Similarly, Tong et al. (2015) showed that vegetation could either decrease or increase PM concentration, depending on the roadcanopy configuration, particle size, and local flow field. By studying the effects of urban park/forest vegetation on air pollutants and particles deposition, Setälä et al. (2013) found that pollutant concentrations were often only slightly lower under tree canopies than in adjacent open areas. For these reasons, some authors argue that the positive effects of vegetation on the urban environment can be exaggerated (Whitlow et al., 2014).

Nonetheless, urban green areas recognisably play various social and health benefits and are recreational outdoor public spaces (Zhou and Rana, 2012; Donovan, 2017; Schebella et al., 2019). For maximising environmental, social and health benefits, urban green areas should be free from pollutants of anthropogenic sources, namely from air pollutants. In this paper, urban green areas are classified as Sensitive Areas in Urban Spaces (SAUS) that perform critical environmental and social functions and benefits on urban spaces. As SAUS are particularly vulnerable to anthropogenic pollutant activities, they should be planned preventively in strict articulation with the remaining urban area, namely for: i) planning and designing SAUS effectively to protect these areas from air pollution; ii) monitoring/sensoring the environmental quality of SAUS; and iii) preserving SAUS from receiving undesirable pollution from the surrounding urban area. Thus, the concept of SAUS can help the adoption of planning policies to improve the environmental performance and the conditions provided by urban green areas. A description and the implementation of this concept are provided in the following sections.

\section{Material and methods}

\subsection{Methodology}

The methodological steps of the study are as follows: i) spatial criteria adopted to define SAUS; ii) emissions inventory from linear sources (roads) and point sources (industrial plants) at SAUS; iii) producing and validating maps representing the horizontal concentration of air pollutants at SAUS; and iv) calculating the impact release by sources located at the SAUS's buffers.

The first step of the work consisted of spatially defining the concept of SAUS. For an effective protection of urban green areas from surrounding undesirable air pollution sources, SAUS are proposed within a protective buffer of $300 \mathrm{~m}$. The proposed buffer of $300 \mathrm{~m}$ has a preventive function that aims to protect and avoid installing new pollutant sources in this area. This distance was selected because various studies show that air pollutant concentrations decay within $300 \mathrm{~m}$ from the source, especially in terms of traffic pollutants. For instance, Hoek et al. (2008) provided a detailed overview of land-use regression models to assess spatial variation of outdoor air pollution showing that $300 \mathrm{~m}$ is a distance often used for analysing several pollutants. More recently, other authors have shown that air pollution levels disperse from peak levels near the centerline of roadways to background values largely over a distance of about $300 \mathrm{~m}$ (Su et al., 2015; Muttoo et al., 2018). When analysing the impact of industrial emissions on outdoor air pollution, the literature provides several examples using different distances. However, a radius of $300 \mathrm{~m}$ from industrial sources has also been used by some authors (Tunno et al., 2015; Subba et al., 2016; Wolf et al., 2017). On the other hand, the peak of $\mathrm{SO}_{2}$ from industrial plants studied by Macit and Gümrükçüoğlu (2012) occurs at $300 \mathrm{~m}$ decreasing progressively as the distance increases.

Thus, the concept of SAUS was developed considering a protective buffer of $300 \mathrm{~m}$ around the urban green areas. Pollutant emissions in this buffer should be inventoried, and the influence of these emissions on the SAUS quantified and evaluated. The air pollutants selected for testing the concept of SAUS were nitrogen oxide $\left(\mathrm{NO}_{\mathrm{x}}\right)$, sulfur dioxide $\left(\mathrm{SO}_{2}\right)$ and particulate matter $10\left(\mathrm{PM}_{10}\right.$ - particulate matter $\left.\leq 10 \mu \mathrm{m}\right)$. These three air pollutants were selected by considering their harmfulness (EEA, 2014; Su et al., 2015; Silva, 2015) and by the fact of being mainly emitted by traffic and industry (Subba et al., 2016; Abhijith et al., 2017; Silva et al., 2014).

The second step of the work is the inventory of air pollutants. Industrial plants were modelled and represented by points. Exposure to industrial pollution consisted of evaluating the amount of pollutants emitted by plants located in the buffer areas. In Portugal, data from industrial emissions are provided by the Portuguese Environment Agency (PEA). The most recent data available are from 2015 (PEA, 2015). Data collected for analysing these emissions were: type of industry; working time; type of fuel; annual fuel consumption; stack height; flow emission; and stack location. The methods proposed by CORINAIR 2016 (EEA, 2016) and by the Intergovernmental Panel on Climate Change 2006 (IPCC, 2006) can be used for estimating the pollutants emitted by industrial plants. Thus, emissions can be estimated according to the emission factors, per pollutant, in $\mathrm{g} / \mathrm{GJ}$ or $\mathrm{kg} /$ GJ, fuel consumption in ton or $\mathrm{m}^{3}$, and to the lower heating value of the fuel used in $\mathrm{GJ} / \mathrm{t}$ or $\mathrm{GJ} / \mathrm{m}^{3}$, as shown in Eq. 1:

Emission $_{i}=E F_{i} \times(C C \times P C I) \times 10^{-6}$

with: 
Table 1

Emission factors $(\mathrm{g} / \mathrm{GJ})$ of $\mathrm{NO}_{\mathrm{x}}, \mathrm{PM}_{10}$ and $\mathrm{SO}_{2}$ according to the engine power and fuel type.

Source: (i) EEA, 2016; (ii) EEA, 2014.

\begin{tabular}{|c|c|c|c|c|c|}
\hline Pollutant & $\mathrm{NO}_{\mathrm{x}}$ & & $\mathrm{PM}_{10}$ & & $\mathrm{SO}_{2}$ \\
\hline Power & $<50 \mathrm{Mw}$ & $>50 \mathrm{Mw}$ & $<50 \mathrm{Mw}$ & $>50 \mathrm{Mw}$ & - \\
\hline Natural gas & 74 (i) & 89 (i) & 0.78 (i) & 0.89 (i) & 0.5 (ii) \\
\hline LPG & 70 (ii) & 89 (ii) & 0.5 (ii) & 0.9 (ii) & \\
\hline
\end{tabular}

Table 2

Lower calorific values according to the fuel type. Source: IPCC (2006)

\begin{tabular}{ll}
\hline Fuel Type & Lower Calorific Value \\
\hline Natural gas & $38,44 \mathrm{GJ} /\left(\mathrm{Nm}^{3} \times 10^{3}\right)$ \\
LPG & $48,45 \mathrm{GJ} / \mathrm{t}$ \\
\hline
\end{tabular}

Emission $_{i}-$ Emission of pollutant $i(\mathrm{t} /$ year $)$

$E F_{i}-$ Emission factor of pollutant $i(\mathrm{~g} / \mathrm{GJ})$

$C C$ - Fuel consumption (t or $\mathrm{m}^{3} /$ year)

$P C I$ - Lower heating value $\left(\mathrm{GJ} / \mathrm{t}\right.$ or $\left.\mathrm{GJ} / \mathrm{m}^{3}\right)$
Table 3

Industrial plants and traffic volume in the buffers of the main urban green areas of Guimarães.

\begin{tabular}{|c|c|c|c|}
\hline $\begin{array}{l}\text { Urban Green } \\
\text { Areas }\end{array}$ & $\begin{array}{l}\text { Area } \\
\text { (Ha) }\end{array}$ & $\begin{array}{l}\text { Number of plants } \\
\text { (Medium/big size) }\end{array}$ & $\begin{array}{l}\text { Vehicles.km/day * } \\
\text { (buffer) }\end{array}$ \\
\hline Campus de Azurém & 22 & 1 & 71,651 \\
\hline Monte da Penha & 45 & 0 & 7,514 \\
\hline Parque da Cidade da Costa & 22 & 0 & 25,664 \\
\hline Parque da Cidade Desportiva & 16 & 0 & 5,507 \\
\hline Parque das Taipas/Ponte & 16 & 0 & 26,511 \\
\hline Parque do Rio Selho & 14 & 1 & 34,046 \\
\hline
\end{tabular}

* Number of vehicles per $\mathrm{km}$ of road per day.

The pollutant emission factors (Table 1) and lower fuel calorific values (Table 2) can be adopted according to regional and national inventories, including CORINAIR (EEA, 2014, 2016) and IPCC (2006).

Furthermore, roads were modelled as linear sources of air pollutants. Data required for this analysis include traffic flows, type and age of vehicles and speed. Based on these data, emissions from traffic can be estimated according to Equation 4.

Emission $_{i}=\sum_{i}(E F \times N \times L) \times 10^{-6}$

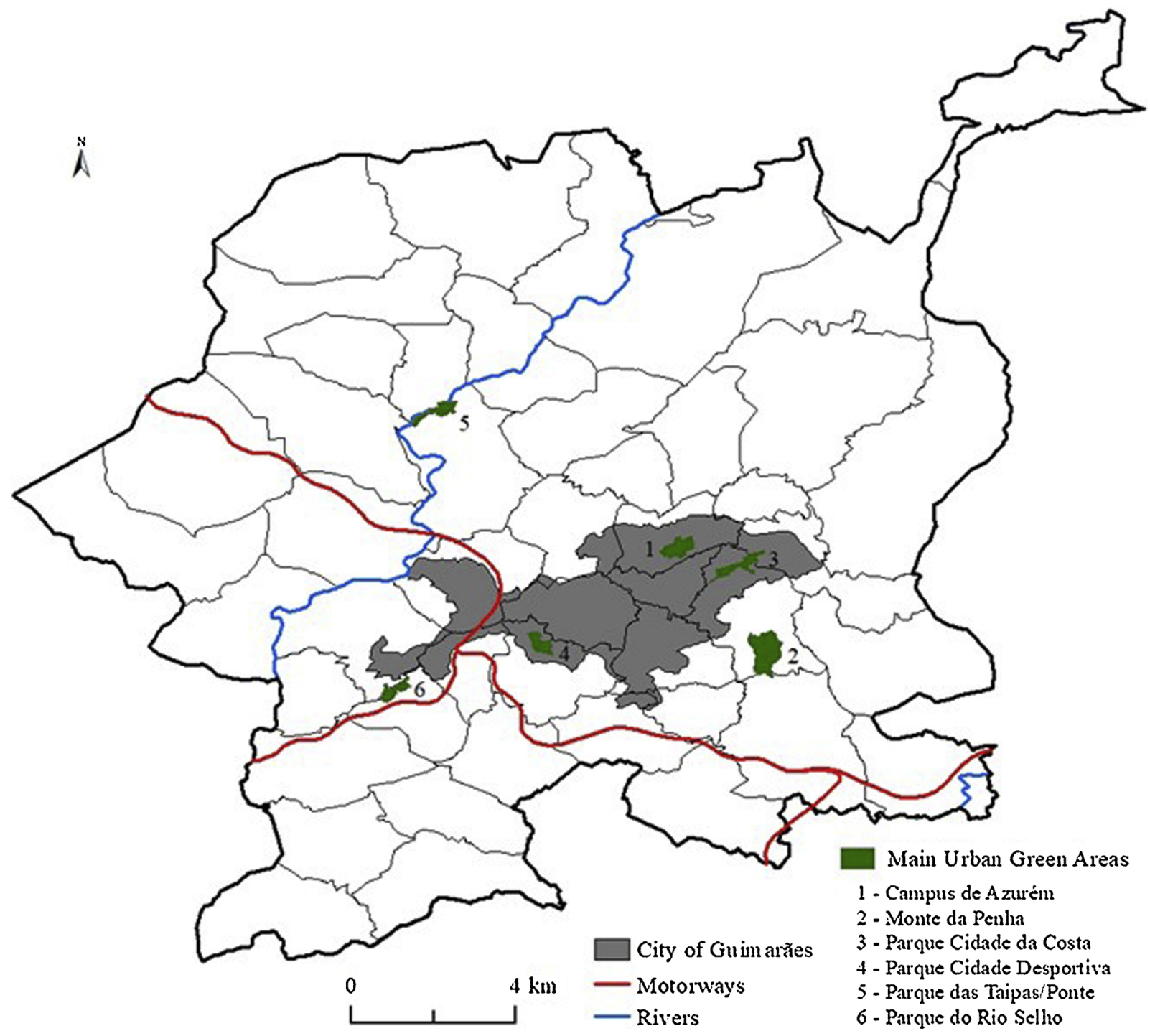

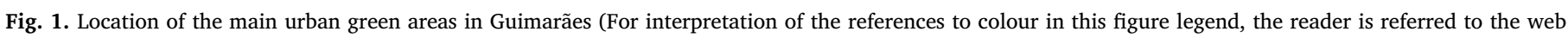
version of this article).

Source: MG, 2015. 
Table 4

Industrial and traffic indicators at Parque do Rio Selho and Campus de Azurém.

\begin{tabular}{|c|c|c|c|c|c|c|c|c|}
\hline \multirow[t]{2}{*}{ SAUS ID } & \multicolumn{2}{|l|}{ Surface } & \multicolumn{3}{|c|}{ Industrial plants } & \multicolumn{3}{|l|}{ Traffic } \\
\hline & SAUS (Ha) & Buffer (Ha) & Number & Type & Size & $\begin{array}{l}\text { Road } \\
\text { Type }\end{array}$ & Length (m) & $\begin{array}{l}\text { Vehicles/ } \\
\text { day }\end{array}$ \\
\hline Parque do Rio Selho & $14 \mathrm{Ha}$ & $184 \mathrm{Ha}$ & 1 & Textile & Big & $\begin{array}{l}\text { Arterial } \\
\text { Secondary } \\
\text { Local access }\end{array}$ & $3858 \mathrm{~m}$ & 115.184 \\
\hline Campus de Azurém & $22 \mathrm{Ha}$ & 196 На & 1 & Textile & Medium & $\begin{array}{l}\text { Main road } \\
\text { Secondary } \\
\text { Local access }\end{array}$ & $4736 \mathrm{~m}$ & 422.918 \\
\hline
\end{tabular}

Table 5

Measuring equipment.

\begin{tabular}{ll}
\hline Parameters & Method \\
\hline Temperature and relative humidity & $\begin{array}{l}\text { Thermo-hygrometry. Air temperature at } 1.5 \mathrm{~m} \text { height, } \\
\text { average from the last } 10 \mathrm{~min} \text { of each hour }\left({ }^{\circ} \mathrm{C}\right) .\end{array}$ \\
Wind speed and direction & Ultrasonic anemometry $2 \mathrm{D}$. Wind speed (m/s) and direction $(-)$, average from the last 10 min of each hour. \\
\hline
\end{tabular}

Table 6

$\mathrm{NO}_{\mathrm{x}}$ modelled and measured at Azurém Automatic Station.

\begin{tabular}{llll}
\hline $\begin{array}{l}\text { Air } \\
\text { pollutant }\end{array}$ & $\begin{array}{l}\text { Monitoring and modelled } \\
\text { statistics indicators }\end{array}$ & & $\begin{array}{l}\text { Values } \\
\left(\mu \mathrm{g} / \mathrm{m}^{3}\right)\end{array}$ \\
\hline $\mathrm{NO}_{\mathrm{x}}$ & $\begin{array}{l}\text { Monitoring data } \\
\text { (PEA, 2017) }\end{array}$ & $\begin{array}{l}\text { Average } \\
\text { Standard deviation }\end{array}$ & $\begin{array}{l}26.7 \\
\end{array}$ \\
& Modelled data & $\begin{array}{l}\text { Average } \\
\text { Standard deviation }\end{array}$ & 24.9 \\
& & 6.2 \\
\hline
\end{tabular}

Table 7

Emissions from point and linear sources at both SAUS.

\begin{tabular}{|c|c|c|c|c|c|c|}
\hline $\begin{array}{l}\text { Air } \\
\text { pollutants }\end{array}$ & $\begin{array}{l}\text { Road } \\
\text { traffic } \\
\text { (t/year) } \\
\text { Parque d }\end{array}$ & $\begin{array}{l}\text { Industry } \\
\text { (t/year) }\end{array}$ & $\begin{array}{l}\text { Total } \\
\text { emission } \\
\text { (t/year) }\end{array}$ & $\begin{array}{l}\text { Road } \\
\text { traffic } \\
\text { (t/year) } \\
\text { Campus }\end{array}$ & $\begin{array}{l}\text { Industry } \\
\text { (t/year) }\end{array}$ & $\begin{array}{l}\text { Total } \\
\text { emission } \\
\text { (t/year) }\end{array}$ \\
\hline $\mathrm{NO}_{\mathrm{x}}$ & 8.94 & 36.78 & 45.72 & 18.19 & 8.05 & 26.24 \\
\hline $\mathrm{PM}_{10}$ & 0.52 & 0.39 & 0.91 & 1.07 & 0.08 & 1.15 \\
\hline $\mathrm{SO}_{2}$ & 0.02 & 0.14 & 0.16 & 0.03 & 0.03 & 0.06 \\
\hline
\end{tabular}

were:

Emission $_{i}$ - Pollutant emission (t/year)

$E F$ - Pollutant emission factor (g/km.veh)

$N$ - Number of vehicles per road section (veh/year)

$L$ - Length of road section $(\mathrm{km})$

The next step of the work consists of producing the maps representing the horizontal concentration of air pollutants. The CadnaA software option APL was used to create the horizontal maps of $\mathrm{NO}_{\mathrm{x}}$, $\mathrm{PM}_{10}$ and $\mathrm{SO}_{2}$. This software uses the dispersion model AUSTAL2000 developed by the German National Environmental Protection Agency. This model has been used by several authors to produce horizontal concentration maps of air pollutants (Gerharz et al., 2013; Silva, 2015; Paas and Schneider, 2016). The model AUSTAL2000 requires the following parameters:

- Meteorological conditions: wind speed $(\mathrm{m} / \mathrm{s})$ and wind direction (degrees) for calculating the wind fields. Hourly data from 2015 provided by the Portuguese Institute for Sea and Atmosphere.

- Buildings geometry and heights (m). Spatial data provided by the municipality of Guimarães.

- Stack height: 15 m (PEA, 2015).

- Road network. Spatial data provided by the municipality of Guimarães
- Topography: field counter lines ( 5 per $5 \mathrm{~m}$ ). Spatial data provided by the municipality of Guimarães.

- Grid spacing: $5 \mathrm{~m}$ (x, y-levels). Model parameter (Cadna, 2010).

- Height of the map: $1.20 \mathrm{~m}$ (z-level). $1.20 \mathrm{~m}$ corresponds to the average height of the nose of human beings (Silva and Mendes, 2012).

- Roughness length: $0.5 \mathrm{~m}$. This parameter characterises the turbulence conditions of the atmospheric boundary layer (Silva and Mendes, 2012).

- Industrial emissions inventory: database prepared in the previous step (Tables 1 and 2).

- Reference year: 2015 (emissions factors from road traffic, Cadna, 2010).

- Average traffic speed: CadnaA-APL emission factors are provided for various traffic situations depending on their average speed (HBEFA, 2004). The average speed considered in this study was: i) urban roads: $32 \mathrm{~km} / \mathrm{h}$ for light vehicles and $18.1 \mathrm{~km} / \mathrm{h}$ for heavy vehicles; ii) motorways: $120 \mathrm{~km} / \mathrm{h}$ for light vehicles and $86.2 \mathrm{~km} / \mathrm{h}$ for heavy vehicles. All these values were obtained by the CadnaA-APL option user manual (Cadna, 2010), according to the specifics traffic situations.

- Traffic related emissions per hour: The emissions per hour were obtained from traffic flows, composition, speeds, and reference year (HBEFA, 2004). For instance, the emission factors of one light vehicle travelling at $32 \mathrm{~km} / \mathrm{h}$ are: $0.238 \mathrm{~g} / \mathrm{km}$ of $\mathrm{NO}_{\mathrm{x}}, 0.058 \mathrm{~g} / \mathrm{km}$ of $\mathrm{PM}_{10}$ and $0.001 \mathrm{~g} / \mathrm{km}$ of $\mathrm{SO}_{2}$ (Cadna, 2010).

-Topography (digital terrain model) and buildings data: to include the effects of these objects on the creation of local wind fields and air pollutants dispersion. Model parameter (Cadna, 2010).

- Output: hourly average concentrations of $\mathrm{NO}_{\mathrm{x}}\left[\mu \mathrm{g} / \mathrm{m}^{3}\right], \mathrm{PM}_{10}[\mu \mathrm{g} /$ $\left.\mathrm{m}^{3}\right]$ and $\mathrm{SO}_{2}\left[\mu \mathrm{g} / \mathrm{m}^{3}\right]$.

The validation process proposed in this paper consists of comparing the values of $\mathrm{NO}_{\mathrm{x}}$ modelled and measured by a fixed automatic monitoring station located at SAUS. Using $\mathrm{NO}_{\mathrm{x}}$ to validate the results is justified by two reasons: i) it is a common air pollutant (Wang and Schneider, 2011; Wang et al., 2016); and ii) the main sources of $\mathrm{NO}_{\mathrm{x}}$ are traffic and industrial activity (Chen et al., 2018). The software adopted in this study to visualise and analyse the simulation results was ArcGIS 10.5 .

Finally, it should be highlighted that the results of the described method are only supported on local emission sources since background 


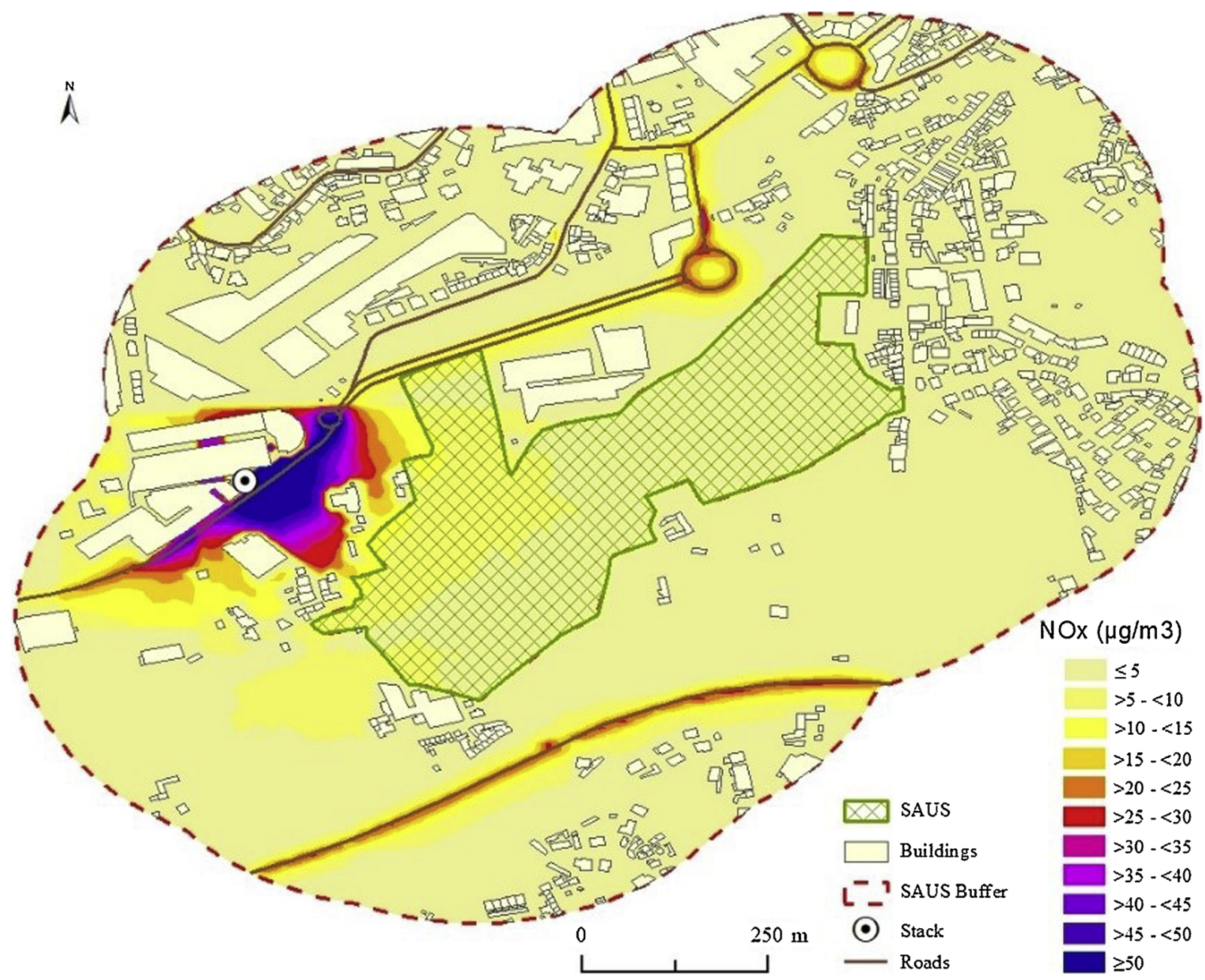

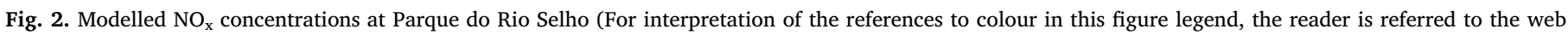
version of this article).

pollution, as well as the pollution from diffused sources, including other point, mobile, area and biogenic emissions, were not included in the model. In Portugal, data from background and pollution from diffused sources is provided by the Portuguese Environment Agency (PEA, 2017). In Guimarães and according to PEA (2017), the background values for the three pollutants are the following: $\mathrm{NO}_{\mathrm{x}}=22.8 \mu \mathrm{g} / \mathrm{m}^{3}$, $\mathrm{PM}_{10}=9.0 \mu \mathrm{g} / \mathrm{m}^{3}$, and $\mathrm{SO}_{2}=2.2 \mu \mathrm{g} / \mathrm{m}^{3}$.

\subsection{Case study}

The SAUS concept was implemented in Guimarães, a Portuguese medium-sized city with approximately 52,000 inhabitants (SP, 2012). Guimarães is known for the integrity and quality of its historic centre that is included in the UNESCO World Heritage List. Guimarães is a municipality that has an economy strongly underpinned in industrial sectors, mainly in textile and leather goods.

Guimarães was chosen to develop the described concept for four main reasons. Firstly, the municipality has an ambitious environmental agenda due to being shortlisted for the European Green Capital Award 2020. The policies adopted for improving air quality intend to meet EU goals and are included in the AQMP (Air Quality Management Program). The city agenda prioritises the preservation of "air quality even when it is good" (MG, 2018). Secondly, 66\% of the residents in Guimarães live less than $200 \mathrm{~m}$ from an urban green area (MG, 2018). Thirdly, with $22.5 \mathrm{~m}^{2} /$ inhabitant, Guimarães presents a ratio of urban green areas above the value recommended by the United Nations $\left(20 \mathrm{~m}^{2}\right.$ /inhabitant). Fourthly, besides the good performance in terms of surface and access, some of the urban green areas are located near air pollution sources: industries and roads. Therefore, the environmental quality of these spaces may be affected by anthropogenic activities.

The next step of the work consisted of selecting urban green areas for implementing the SAUS concept. According to the municipal master plan (MG, 2015), Guimarães has six main urban green areas (Fig. 1). In this paper, it was assumed that industrial plants and traffic in the vicinities of the green areas could potentially affect their environmental performance in terms of air pollutants. Thus, for each one of the six main urban green areas of Guimarães, the volume of road traffic and the number of plants producing emissions in their vicinities (in a buffer of $300 \mathrm{~m}$ ) were analysed. In Portugal and according to the legislation (Decree-law $127 / 2013$ of August $30^{\text {th }}$ ), small and micro industries do not need environmental licenses for operating. Therefore, data from industrial emissions are only available for medium or large sized industries. For that reason, only data from medium and large industrial plants with operating licenses were considered in the selection process.

As shown in Table 3, two green areas are known for having a higher traffic volume and more plants producing emissions in their vicinities: Campus de Azurém and Parque do Rio Selho. Therefore, these two urban green areas were selected to implement the concept of SAUS.

Roads crossing the buffers were extracted from a geographical database provided by the municipality of Guimarães by clipping the roads that were within the buffer. Roads crossing the buffer were defined as arterial (motorways), main roads (bypasses), secondary (national roads) and minor (local access). Traffic emissions of $\mathrm{NO}_{\mathrm{x}}, \mathrm{SO}_{2}$ and $\mathrm{PM}_{10}$ were estimated according to the respective emission factor (PEA, 2016). 


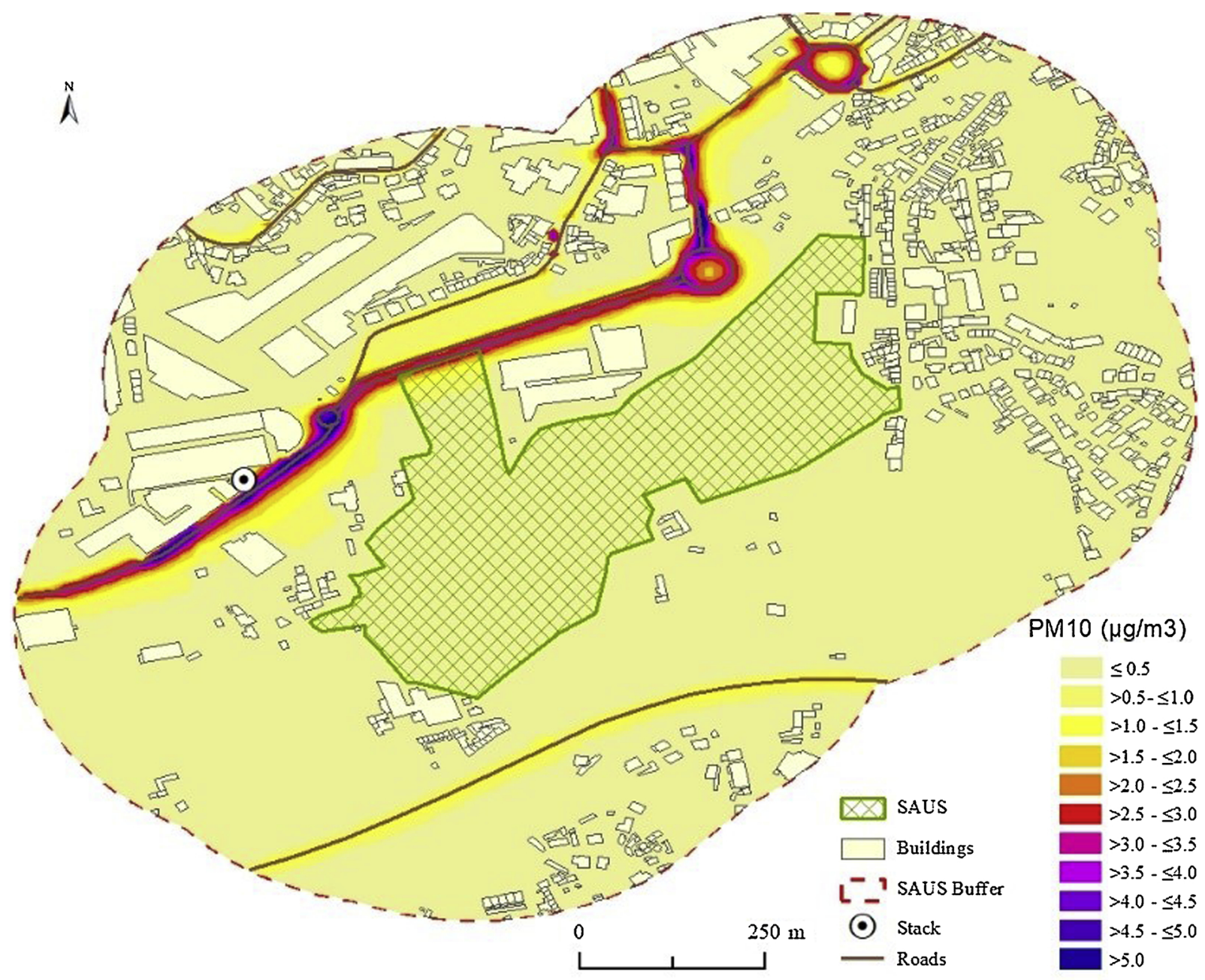

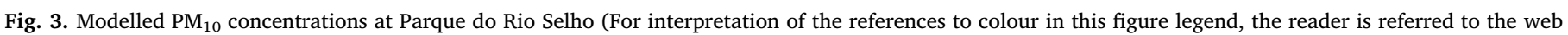
version of this article).

Data from traffic, including the type of fuel, the type of vehicle and age of vehicle in Guimarães, were collected from the Insurance and Pension Funds Supervisory Authority (IPFSA, 2017). Detailed data of traffic flows, type of vehicles and speed were obtained from a traffic counting campaign carried out in 2016 in a round-the-clock typical weekday. On the motorway, traffic was counted during $24 \mathrm{~h}$ in a weekday, while in the remaining roads, traffic was estimated using counts of one hour in each road. These values were extrapolated using a 24 -hs traffic curve as reference. More details about the industrial plants and traffic at both SAUS are presented in Table 4.

Meteorological data used in the study came from the automatic station located in Merelim (Braga) and was provided by the Portuguese Institute for Sea and Atmosphere. Merelim is the closest meteorological station from Guimarães (about $7 \mathrm{~km}$ ). Data provided by the meteorological station included temperature, wind speed and direction, as well as precipitation. Merelim is located in Northern Portugal and has a Csb climate (warm-Summer Mediterranean climate) according to the Köppen-Geiger classification (Parente et al., 2016). The 30-year averages at Merelim are described by an average temperature of $14.5^{\circ} \mathrm{C}$, a total annual precipitation of $1466 \mathrm{~mm}$, and Northwest predominant winds. Table 5 describes the equipment used at the meteorological station of Merelim.

As described in the Methodology, the pollutant used in the validating process was $\mathrm{NO}_{\mathrm{x}}$, a typical urban pollutant. The Portuguese Environment Agency has a monitoring station located near the Campus de Azurém where several air pollutants, including $\mathrm{NO}_{\mathrm{x}}$, are measured.
The validation process consisted of comparing the $\mathrm{NO}_{\mathrm{x}}$ values measured in the PEA station with those modelled in this study. The comparison was made by using the average and standard deviation values considering the period between 25 November to 9 December 2016. Results are presented in Table 6. The difference between the average values provided by the PEA (2017) and the average modelled values was not significant $\left(1.8 \mu \mathrm{g} / \mathrm{m}^{3}\right)$. The same is valid for the standard deviation values. Therefore, results confirm the generally good performance of the proposed method.

\section{Results}

\subsection{Air pollutant emission}

The first step of the work consisted of estimating the $\mathrm{NO}_{\mathrm{x}}, \mathrm{SO}_{2}$, and $\mathrm{PM}_{10}$ emissions for both urban green areas according to the methodology described. As can be concluded from Table 7, at Parque do Rio Selho, more than $80 \%$ of $\mathrm{NO}_{\mathrm{x}}$ and $\mathrm{SO}_{2}$ emissions were produced by the industrial plant. In turn, road traffic was responsible for $57 \%$ of the $\mathrm{PM}_{10}$ emissions estimated. Besides, at Campus de Azurém, road traffic is more determinant in the $\mathrm{NO}_{\mathrm{x}}$ emissions, as well as $\mathrm{PM}_{10}$, which is typically a traffic pollutant.

\subsection{Air pollutant concentration}

The next step consisted of developing and validating the horizontal air pollutant concentration maps. The software ArcGIS 10.5 was used to 


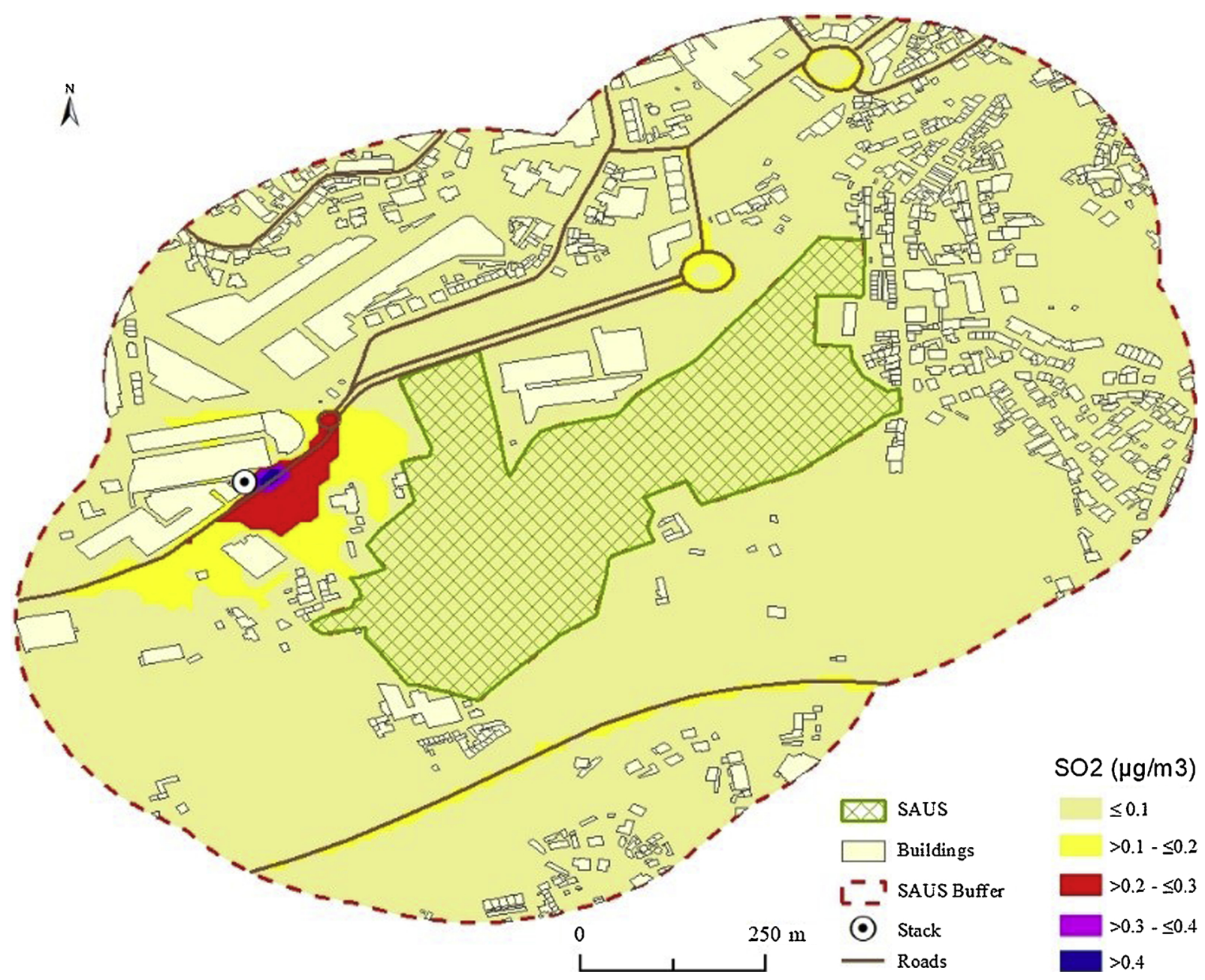

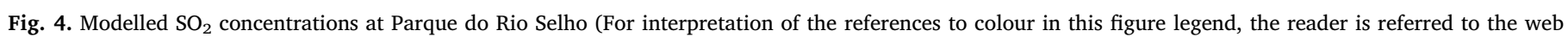
version of this article).

produce the maps representing the concentrations of $\mathrm{NO}_{\mathrm{x}}, \mathrm{PM}_{10}$ and $\mathrm{SO}_{2}$ of both SAUS (Figs. 2-7) by using the simulation results from CadnaA-APL software. These maps represent the annual average situation of the atmospheric pollution. In the case of Parque do Rio Selho, road traffic and the industrial plant have an environmental impact on the SAUS. The impact of the industrial plant is particularly significant in terms of $\mathrm{NO}_{\mathrm{x}}$. As shown in Fig. 2, exposure to classes of concentrations of $5-10$ and $10-15 \mu \mathrm{g} / \mathrm{m}^{3}$ were detected within this SAUS. However, the highest concentration of $\mathrm{NO}_{\mathrm{x}}$ found was $105 \mu \mathrm{g} / \mathrm{m}^{3}$ around the plant stack.

Regarding the concentration for $\mathrm{PM}_{10}$ (Fig. 3), the SAUS of Parque do Rio Selho is predominantly exposed to levels lower than $0.5 \mu \mathrm{g} / \mathrm{m}^{3}$. However, the area near the road, in the North sector of the SAUS, has concentrations of $3.5 \mu \mathrm{g} / \mathrm{m}^{3}$. On other hand, the motorway does not influence the concentration of this pollutant due to the greater distance to the urban green area. Thus, the proximity to roads is a factor which has a direct impact on the concentration levels of $\mathrm{PM}_{10}$. Results also indicate that road traffic has a higher impact than the industrial plant in concentrations of $\mathrm{PM}_{10}$ at this SAUS.

Finally, in terms of $\mathrm{SO}_{2}$, results show that industry exerts a strong influence on the concentration of this pollutant, although its impact within the SAUS is reduced (Fig. 4). The maximum concentration of $\mathrm{SO}_{2}$ is $0.5 \mu \mathrm{g} / \mathrm{m}^{3}$, but this level is only found outside the SAUS, near the plant stack. At the SAUS, the dominant concentration is much lower $\left(0.1 \mu \mathrm{g} / \mathrm{m}^{3}\right)$ and only a small fraction of the green area closer to the industrial plant has concentrations of $0.2 \mu \mathrm{g} / \mathrm{m}^{3}$. Road traffic has no impact on the concentration of $\mathrm{SO}_{2}$ at the SAUS.
The described method was adopted similarly to understand the impact that road traffic and the industrial activity exerts on the concentration of air pollutants at the SAUS of Campus de Azurém and in its respective buffer. In terms of $\mathrm{NO}_{\mathrm{x}}$, the highest concentrations obtained were $67 \mathrm{ug} / \mathrm{m}^{3}$ near the bypass that crosses the Northern area of the buffer. This road does not have a direct impact on the $\mathrm{NO}_{\mathrm{x}}$ concentrations at the SAUS. However, a local access road has a slight impact on the Western sector of this SAUS. $\mathrm{NO}_{\mathrm{x}}$ concentration at this sector has reached $15-20 \mathrm{ug} / \mathrm{m}^{3}$ (Fig. 5). The industrial plant located in the buffer area has no visible impact on the concentrations of this pollutant at the SAUS.

Concerning the concentrations of $\mathrm{PM}_{10}$ at Campus de Azurém, concentrations are mostly explained by road traffic. As shown in Fig. 6, the nearest road to SAUS has an impact on its Western sector. Although the dominant concentration of $\mathrm{PM}_{10}$ in this SAUS is $0.03 \mu \mathrm{g} / \mathrm{m}^{3}$, in the Western sector the exposure increases to $5.28 \mu \mathrm{g} / \mathrm{m}^{3}$. In turn, the most distant roads, as well as the industrial plant, do not produce visible impacts on the $\mathrm{PM}_{10}$ concentrations at the SAUS.

The sources identified do not produce significant impacts on the concentration of $\mathrm{SO}_{2}$ at Campus de Azurém. Thus, the concentrations are globally low ranging from 0.1 to $0.2 \mathrm{ug} / \mathrm{m}^{3}$. The highest values are also detected in the Western sector, near the local access road.

\subsection{Areas affected by air pollution}

The ArcGIS 10.5 software was also used to make an in-depth spatial analysis about the concentration of pollutants, namely for estimating 


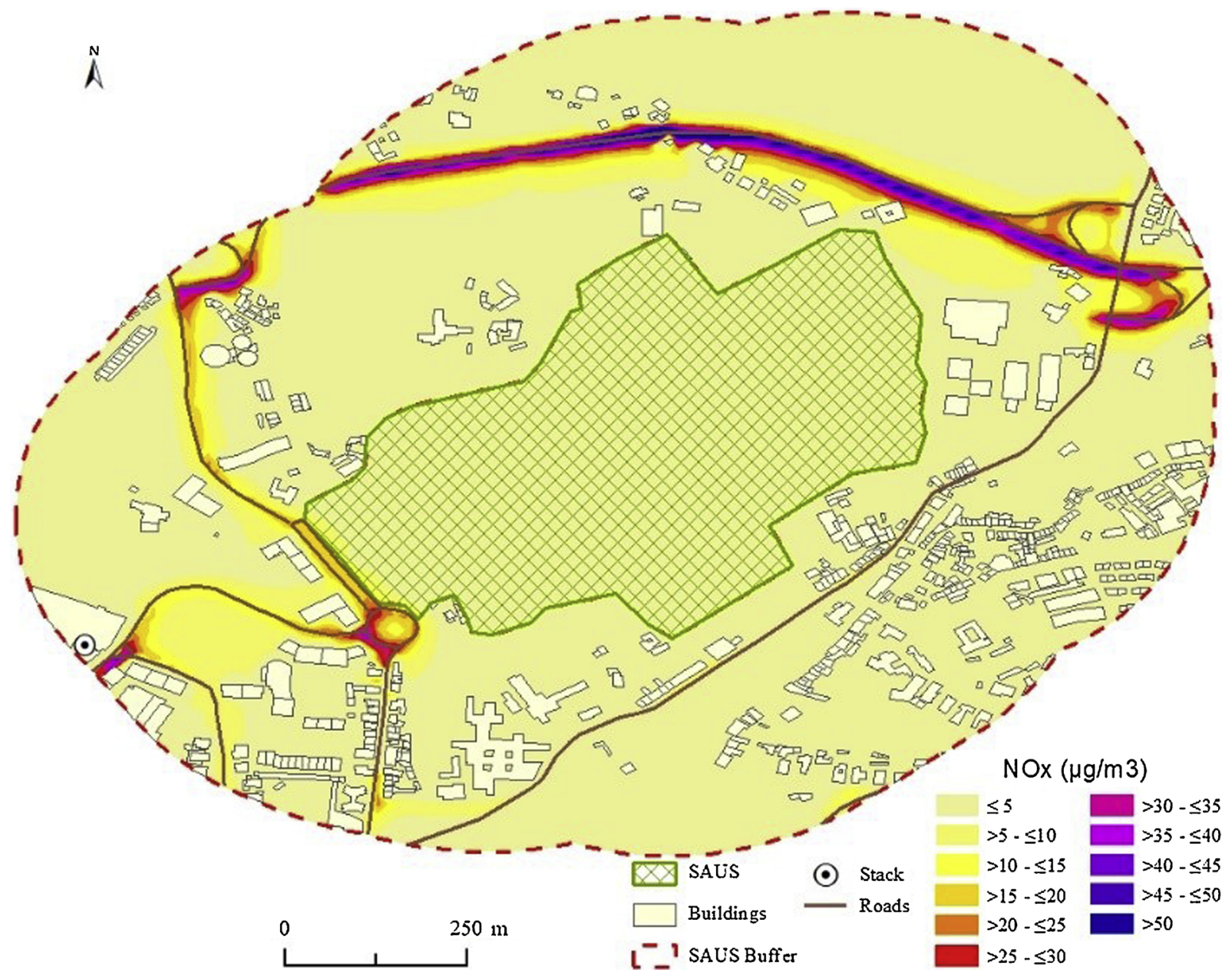

Fig. 5. Modelled $\mathrm{NO}_{\mathrm{x}}$ concentrations at Campus de Azurém (For interpretation of the references to colour in this figure legend, the reader is referred to the web version of this article).

the areas exposed to the different concentrations of $\mathrm{NO}_{\mathrm{x}}, \mathrm{PM}_{10}$ and $\mathrm{SO}_{2}$ at both SAUS. Table 8 presents the results of this spatial analysis. Results show that the sources located at both buffers were having impacts on SAUS. However, these impacts are reduced as most of the SAUS was exposed to the class with the lowest concentration of each pollutant. The only exception is the concentration of $\mathrm{NO}_{\mathrm{x}}$ at Parque do Rio Selho where $25.6 \%$ of the SAUS was exposed to the class with a concentration of 5 to $\leq 10 \mu \mathrm{g} / \mathrm{m}^{3}$. At both SAUS, the areas affected by the highest classes of concentrations were residual and closer to zero.

\section{Discussion}

Results from simulation showed that besides the globally low levels of emissions, roadways and industrial plants had environmental impacts at both SAUS. Results also demonstrated that the nearest areas to roadways and plants are the most affected by these sources. Each SAUS has one textile plant installed in the buffer boundary. The industrial plant located at Parque do Rio Selho has more impact than the plant located at Campus de Azurém, mainly in terms of $\mathrm{NO}_{\mathrm{x}}$ and $\mathrm{SO}_{2}$. The highest impact felt by the plant at Parque do Rio Selho is explained by two reasons. First, by the higher emission (ton/year), especially of $\mathrm{NO}_{\mathrm{x}}$ and $\mathrm{SO}_{2}$ of the plant located there (Table 1 ). Second, the plant stack located at Parque do Rio Selho is much closer to the green area $(180 \mathrm{~m})$ than the plant stack located at Campus de Azurém ( $290 \mathrm{~m}$ ). Thus, the emission volume and the distance between the stack and the green area have a direct impact on the concentrations of air pollutants at SAUS. On other hand, results also show that car traffic has a higher impact than industry at both SAUS. Both buffers are crossed by roads with different categories and have different traffic volumes. More traffic causes more concentration of pollutants at SAUS. This is particularly seen at Campus de Azurém. $\mathrm{NO}_{\mathrm{x}}$ and $\mathrm{SO}_{2}$ concentrations are much higher on roads with more traffic (the bypass that crosses the buffer at Northeast) than on other local access roads (Figs. 5 and 7). However, the concentration of $\mathrm{PM}_{10}$ (Fig. 6) is lower due to the higher traffic speed in the bypass. Besides the impact of traffic volume and traffic speed, the distance between the roads and SAUS is also a very relevant factor on the concentrations found in the green areas. In fact, the roads that have more impact on SAUS are not those with more traffic, such as the bypass, but local access roads near the green areas. This is consistent with previous studies showing that air pollutant concentrations from traffic rapidly decrease with distance to roads/motorways (Zhang and Batterman, 2013; Pasquier and André, 2017). The modelled air pollution at both SAUS are globally low, and both line and point sources influenced the spatial distributions of $\mathrm{NO}_{\mathrm{x}}, \mathrm{PM}_{10}$ and $\mathrm{SO}_{2}$. Therefore, more than $97 \%$ of the surface in each SAUS has concentrations equal to or below $5 \mu \mathrm{g} /$ $\mathrm{m}^{3}$ of $\mathrm{NO}_{\mathrm{x}}, 0.5 \mu \mathrm{g} / \mathrm{m}^{3}$ of $\mathrm{PM}_{10}$ and $0.1 \mu \mathrm{g} / \mathrm{m}^{3}$ of $\mathrm{SO}_{2}$. The exception was Parque do Rio Selho, where about $26 \%$ of the surface had a concentration of $>5-\leq 10 \mu \mathrm{g} / \mathrm{m}^{3}$ of $\mathrm{NO}_{\mathrm{x}}$. Even if the background emissions and the emissions from diffused sources provided by the Portuguese Environment Agency for Guimarães (check subsection 3.1) is added, the simulated $\mathrm{NO}_{\mathrm{x}}$ is lower than the EU daily limit values $\left(50 \mu \mathrm{g} / \mathrm{m}^{3}\right)$ and the World Health Organization reference level $(20 \mu \mathrm{g}$ / $\mathrm{m}^{3}$ ) (EEA, 2014).

The obtained results also reflect the performance of specific 


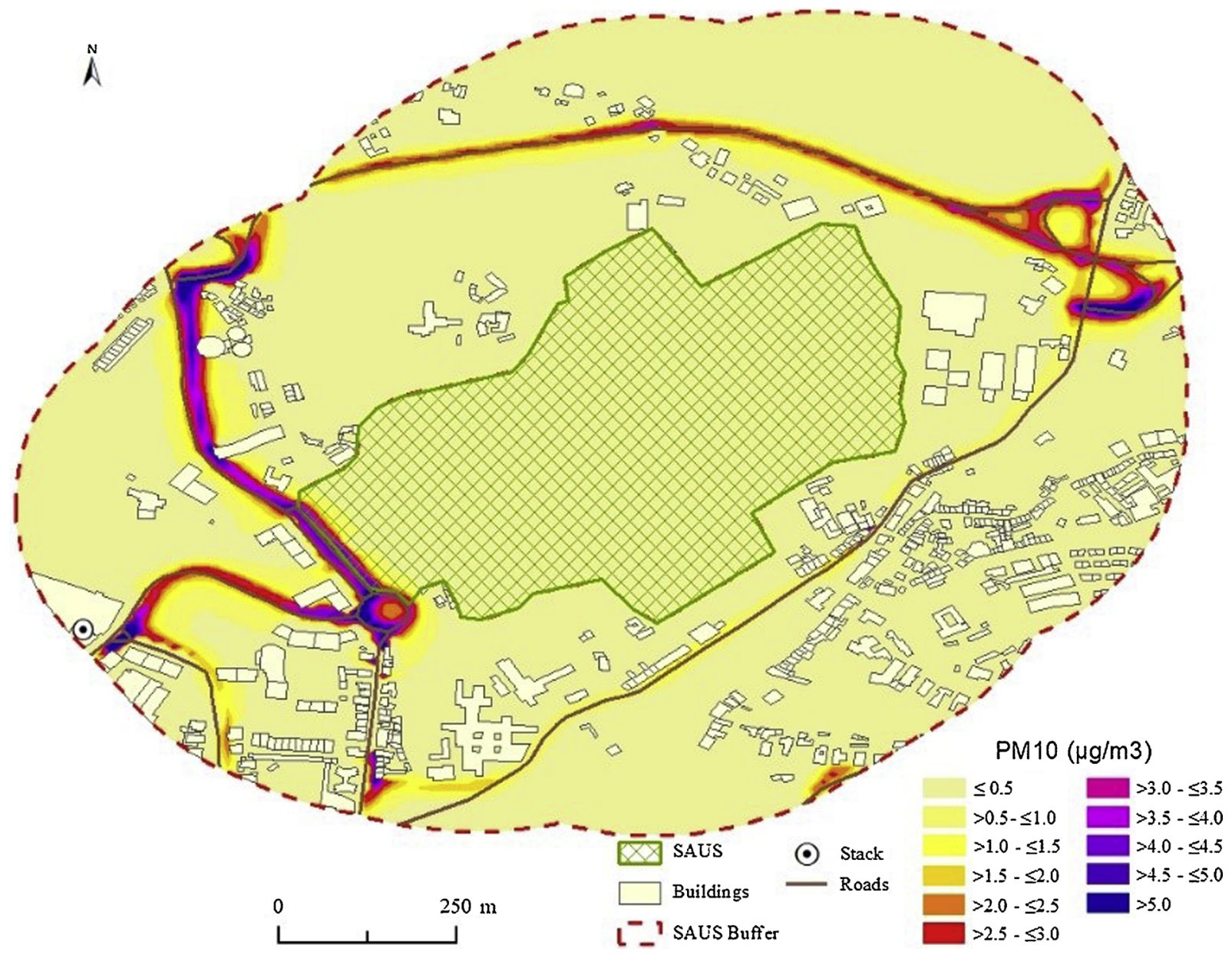

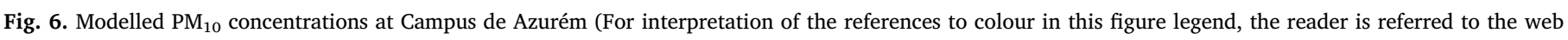
version of this article).

variables, including the height of the stacks, the meteorological conditions, the topography of places and the presence of obstacles, depending on the specificities of these variables, results might be different. As described in the Methodology, the height of the stacks used in this study was $15 \mathrm{~m}$. The height of the stack is inversely related to its impact on the surface pollution levels, since a higher stack results in more dispersion and chemical transformation prior to the plume reaching the ground (Chen et al., 2018). The lowest impact occurs near the base of the stack, and the highest can occur up to several kilometres from the source (Chen et al., 2018). Thus, a higher or smaller stack can produce a different result in the dispersion of the pollutants. In terms of meteorological conditions, the wind always has an important role in the dispersion of the plume (Hoek et al., 2008; Pasquier and André, 2017; Sahu et al., 2018). The model described in this paper includes the annual mean of wind speed and wind direction. In Guimarães, the dominant wind direction which is Northwest has an impact on the pollutant dispersion, mainly at Parque do Rio Selho, where the SAUS is located Southeast of the industrial plant. The SAUS and the source location regarding prevailing winds has a strong impact. When SAUS are located downstream concerning the main sources, the influence is higher since the wind blowing from the emission sources can reach SAUS directly. This effect is visible on the modelled $\mathrm{SO}_{2}$ concentrations at Parque do Rio Selho (Fig. 4). The presence of hills or other relevant obstacles could block and reduce that impact. On the other hand, there are no significant physical obstacles to the wind between the sources and the SAUS. In this case study, the topography does not exert influence on the dispersion as the SAUS and the sources are at similar altitudes: the maximum slope is $20 \mathrm{~m}$ at Parque do Rio Selho and $35 \mathrm{~m}$ at
Campus de Azurém. Furthermore, the simulation model used meteorological data from the closest weather station, which is located at about $7 \mathrm{~km}$ from SAUS. Although the meteorological station and the two SAUS have identical topographic and climatic characteristics, meteorological data may differ over the $7 \mathrm{~km}$. In the literature, there are also some air pollution and environmental studies supported in data from distant meteorological stations (Tan et al., 2012; Paas and Schneider, 2016). However, it is recognised that data from distant meteorological stations could have implications on the ability to compare and understand the simulated results and can introduce uncertainty and limitations in the simulation model (Parvez and Wagstrom, 2018). Thus, the use of meteorological data from a station located $7 \mathrm{~km}$ away from the SAUS may influence the obtained results.

The proposed method is supported on a protective buffer of $300 \mathrm{~m}$ around the SAUS. In the case of the two SAUS analysed, the buffer was large enough to prevent the concentration of high levels of pollutants in the air. The described impacts occur because industrial plants and roads are within the protective buffers. However, there is a need for replicating this model in other case studies to confirm its robustness and the suitability of the buffer. It will be particularly important to test the model with higher stacks and emission sources. In fact, several studies confirm that when the stack is high, the plume sinks down to the ground only after a long distance and after the wind has ensured a better dispersion of the plume (Macit and Gümrükçüoğlu, 2012). On the other hand, the emissions were low. In both SAUS, the $\mathrm{NO}_{\mathrm{x}}$ emissions were 71.9 ton/year (Table 1) which corresponds to $5 \%$ of the emissions produced by the municipal industry and traffic (NPRCDC, 2014). However, $\mathrm{NO}_{\mathrm{x}}$ emissions are much higher in larger cities. For instance, 


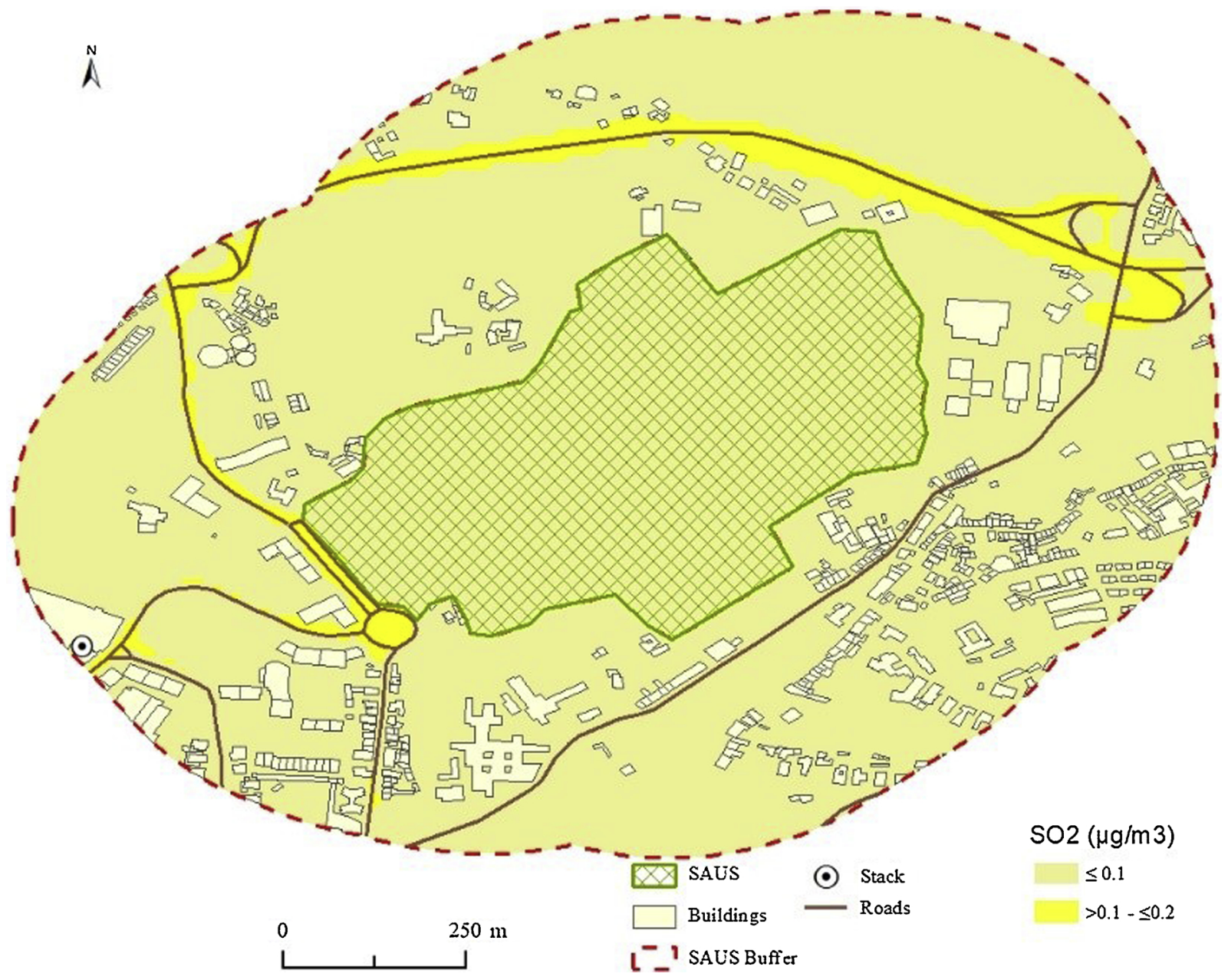

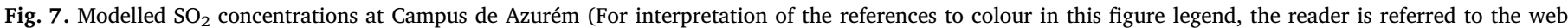
version of this article).

Shahbazi et al. (2016) analysed $\mathrm{NO}_{\mathrm{x}}$ emissions in Tehran and found that industry and traffic were producing 43,000 ton/year (Shahbazi et al., 2016). In Gothenburg, Molnár et al. (2015) estimated $\mathrm{NO}_{\mathrm{x}}$ emissions from traffic and industry at 2000 ton/year. These examples show that emissions are extremely changeable from city to city. On the other hand, various studies have shown that the impact of pollutant sources, such as major roads, on concentrations of air pollutants declines exponentially with distance (Hoek et al., 2008). In this paper, a buffer of $300 \mathrm{~m}$ was used to analyse the impact that the emission from traffic and industrial plants have on the air quality at two SAUS. The buffer size is a crucial variable in determining the performance of the model, and the spatial resolution of the estimates. In compact European urban areas, Hoek et al. (2008) argue that the use of buffer sizes of more than $100-200 \mathrm{~m}$ for traffic intensity may thus be misleading, for they would incorporate sources too far removed to have a significant effect. In contrast, industrial air pollutants depend on industrial activity and of specific factors such as the height of the stack. Typically, industries may produce substantial plume rise, and higher stacks result in more dispersion and chemical transformation before the plume reaching the ground (Chen et al., 2018). Usually, industries produce a low impact near the stack, and a maximum ground-level impact at up to several kilometres downwind from the source (Seinfeld and Pandis, 2006). Thus, in future studies, more applications are needed to test the efficiency of the $300 \mathrm{~m}$ buffer in protecting SAUS from air pollutants, namely of industrial origin. Adjusting and using other buffer sizes should also be tested to ensure that SAUS are efficiently protected from air pollutants.

\section{Conclusions}

Urban green areas are outdoor public spaces performing important environmental and social functions. For that reason, urban green areas should have the best environmental quality for the benefit of their users and urban inhabitants. Despite the large number of studies examining the impact of green urban areas in terms of improving the urban microclimate (cooling effect), on cleaning the air and on reducing noise (Cohen et al., 2012), little research has been conducted for planning these spaces in a sustainable way based on integrated environmental sensitivity analysis. Assessing the environmental quality of urban green areas has been less exploited.

In this paper, urban green areas are classified as Sensitive Areas in Urban Spaces (SAUS). The concept proposed in this study sustains that SAUS should be sufficiently away from industrial plants and roads with high traffic of vehicles, as they are main sources of urban pollution. The concept was developed and implemented in two SAUS of Guimarães, a Portuguese medium-sized city, by defining a buffer of $300 \mathrm{~m}$ around SAUS to preserve them from undesirable surrounding air pollution sources. Industrial plants and car traffic were the sources considered of $\mathrm{NO}_{\mathrm{x}}, \mathrm{PM}_{10}$ and $\mathrm{SO}_{2}$ in the buffers. Maps representing the horizontal concentrations of each pollutant were produced by using the AUSTAL2000 model. Results show that besides the globally low levels of emissions, the sources located in the two buffers had environmental impacts and affected the quality of the air at both SAUS. Thus, these spaces require actions to prevent SAUS from air pollutants and to improve their environmental quality. In a broader view and since SAUS 
Table 8

Areas affected by air pollution at Parque do Rio Selho and Campus de Azurém.

\begin{tabular}{|c|c|c|c|}
\hline SAUS & Pollutant & $\begin{array}{l}\text { Concentration classes } \\
\left(\mu \mathrm{g} / \mathrm{m}^{3}\right)\end{array}$ & $\begin{array}{l}\text { Area exposed to } \\
\text { pollutant classes (\%) }\end{array}$ \\
\hline \multirow{13}{*}{$\begin{array}{l}\text { Parque do Rio } \\
\text { Selho }\end{array}$} & \multirow[t]{4}{*}{$\mathrm{NO}_{\mathrm{X}}$} & $0<\mathrm{NO}_{\mathrm{x}} \leq 5$ & 71.86 \\
\hline & & $5<\mathrm{NO}_{\mathrm{x}} \leq 10$ & 25.64 \\
\hline & & $10<\mathrm{NO}_{\mathrm{x}} \leq 15$ & 2.48 \\
\hline & & $15<\mathrm{NO}_{\mathrm{x}} \leq 20$ & 0.02 \\
\hline & \multirow[t]{7}{*}{$\mathrm{PM}_{10}$} & $0<\mathrm{PM}_{10} \leq 0.5$ & 97.09 \\
\hline & & $0.5<\mathrm{PM}_{10} \leq 1.0$ & 1.43 \\
\hline & & $1.0<\mathrm{PM}_{10} \leq 1.5$ & 0.60 \\
\hline & & $1.5<\mathrm{PM}_{10} \leq 2.0$ & 0.31 \\
\hline & & $2.0<\mathrm{PM}_{10} \leq 2.5$ & 0.22 \\
\hline & & $2.5<\mathrm{PM}_{10} \leq 3.0$ & 0.23 \\
\hline & & $3.0<\mathrm{PM}_{10} \leq 3.5$ & 0.12 \\
\hline & \multirow[t]{2}{*}{$\mathrm{SO}_{2}$} & $0<\mathrm{SO}_{2}<=0.1$ & 99.98 \\
\hline & & $0.1<\mathrm{SO}_{2}<=0.2$ & 0.02 \\
\hline \multirow{16}{*}{$\begin{array}{l}\text { Campus de } \\
\text { Azurém }\end{array}$} & \multirow[t]{4}{*}{$\mathrm{NO}_{\mathrm{X}}$} & $0<\mathrm{NO}_{\mathrm{x}} \leq 5$ & 98.82 \\
\hline & & $5<\mathrm{NO}_{\mathrm{x}} \leq 10$ & 0.79 \\
\hline & & $10<\mathrm{NO}_{\mathrm{x}} \leq 15$ & 0.34 \\
\hline & & $15<\mathrm{NO}_{\mathrm{x}} \leq 20$ & 0.05 \\
\hline & \multirow[t]{10}{*}{$\mathrm{PM}_{10}$} & $0<\mathrm{PM}_{10} \leq 0.5$ & 97.34 \\
\hline & & $0.5<\mathrm{PM}_{10} \leq 1.0$ & 1.01 \\
\hline & & $1.0<\mathrm{PM}_{10} \leq 1.5$ & 0.39 \\
\hline & & $1.5<\mathrm{PM}_{10} \leq 2.0$ & 0.24 \\
\hline & & $2.0<\mathrm{PM}_{10} \leq 2.5$ & 0.18 \\
\hline & & $2.5<\mathrm{PM}_{10} \leq 3.0$ & 0.17 \\
\hline & & $3.0<\mathrm{PM}_{10} \leq 3.5$ & 0.18 \\
\hline & & $3.5<\mathrm{PM}_{10} \leq 4.0$ & 0.20 \\
\hline & & $4.5<\mathrm{PM}_{10} \leq 5.0$ & 0.26 \\
\hline & & $5.0<\mathrm{PM}_{10} \leq 5.5$ & 0.00 \\
\hline & \multirow[t]{2}{*}{$\mathrm{SO}_{2}$} & $0<\mathrm{SO}_{2}<=0.1$ & 99.94 \\
\hline & & $0.1<\mathrm{SO}_{2}<=0.2$ & 0.06 \\
\hline
\end{tabular}

provide various services and functions to urban residents, this study highlighted that urban green areas are invaluable resources that must be adequately planned, maintained and protected.

\section{Funding sources}

This research did not receive any specific grand from funding agencies in the public, commercial, or not-for-profit sectors.

\section{Acknowledgments}

The authors gratefully acknowledge CTAC (Centre for Territory, Environment and Construction) of University of Minho for the use of laboratory facilities, and to the Municipality of Guimarães for providing data and technical support for this research.

\section{References}

Abhijith, K., Kumar, P., Gallagher, J., McNabola, A., Baldauf, R., Pilla, F., Broderick, B., Sabatino, S., 2017. Air pollution abatement performances of green infrastructure in open road and built-up street canyon environments-a review. Atmos. Environ. 162, 71-86.

Bertram, C., Rehdanz, K., 2015. The role of urban green space for human well-being. Ecol. Econ. 120, 139-152.

Cadna, A., 2010. Manual for Option APL, Calculation of Air Pollutants.

Chen, S., Yuvala, Broday, D., 2018. A new modelling approach for assessing the contribution of industrial and traffic emissions to ambient NOx concentrations. Atmos Environ. 173, 173-184.

Cohen, P., Potchter, O., Matzarakis, A., 2012. Daily and seasonal climatic conditions of green urban open spaces in the Mediterranean climate and their impact on human comfort. Build. Environ. 51, 285-295.

Contesse, M., Vliet, B., Lenhart, J., 2017. Is urban agriculture urban green space? A comparison of policy arrangements for urban green space and urban agriculture in Santiago de Chile. Land Use Policy. https://doi.org/10.1016/j.landusepol.2017.11. 006.

Coppel, G., Wüstemann, H., 2017. The impact of urban green space on health in Berlin, Germany: empirical findings and implications for urban planning. Landsc. Urban Plan. 167, 410-418.

Daniels, B., Zaunbrecher, B., Paas, B., Ottermanns, R., Ziefle, M., Roß-Nickoll, M., 2018. Assessment of urban green space structures and their quality from a multidimensional perspective. Sci. Total Environ. 615, 1364-1378.

Depietri, Y., Welle, T., Renaud, F., 2013. Social vulnerability assessment of the Cologne urban area (Germany) to heat waves: links to ecosystem services. Int. J. Disaster Risk Reduct. 6, 98-117.

Donovan, G., 2017. Including public-health benefits of trees in urban-forestry decision making. Urban For. Urban Green. 22, 120-123.

Dzhambov, A., Dimitrova, D., 2015. Green spaces and environmental noise perception. Urban For. Urban Green. 14, 1000-1008.

EEA-European Environment Agency, 2014. Air Pollution Fact Sheet 2014 Portugal. European Environment Agency, Copenhagen.

EEA-European Environment Agency, 2016. EMEP/EEA Air Pollutant Emission Inventory Guidebook 2016. Luxembourg. .

Fang, C., Ling, D., 2005. Guidance for noise reduction provided by tree belts. Landsc. Urban Plan. 71, 29-34.

Fintikakis, N., Gaitani, N., Santamouris, M., Assimakopoulos, M., Assimakopoulos, D., Fintikaki, M., Albanis, G., Papadimitriou, K., Chryssochoides, E., Katopodi, K.,

Doumas, P., 2011. Bioclimatic design of open public spaces in the historic centre of Tirana, Albania. Sustain. Cities Soc. 1, 54-62.

Fonseca, F., Gonçalves, A., Ribeiro, O., 2010. Behaviours and perceptions related to green spaces in the city of Bragança, Portugal. Finisterra 89, 119-139.

Galeeva, A., Mingazova, N., Gilmanshin, I., 2014. Sustainable urban development: urban green spaces and water bodies in the city of Kazan, Russia. Mediterr. J. Social Sci. 5, 356-360.

Gerharz, L., Klemm, O., Broich, A., Pebesma, E., 2013. Spatio-temporal modelling of individual exposure to air pollution and its uncertainty. Atmos. Environ. 64, 56-65.

Gupta, K., Roy, A., Luthra, K., Maithania, S., Mahavir, 2016. GIS based analysis for assessing the accessibility at hierarchical levels of urban green spaces. Urban For. Urban Green. 18, 198-211.

Haq, S., 2011. Urban green spaces and an integrative approach to sustainable environment. J. Environ. Prot. 2, 601-608.

HBEFA, 2004. Handbook Emission Factors for Road Transport (Version 2.1).

Hoek, G., Beelen, R., Hoogh, K., Vienneau, D., Gulliver, J., Fischer, P., Briggs, D., 2008. A review of land-use regression models to assess spatial variation of outdoor air pollution. Atmos. Environ. 42, 7561-7578.

IPCC - Intergovernmental Panel on Climate Change, 2006. IPCC Guidelines for National Greenhouse Gas Inventories. IGES, Japan.

IPFSA - Insurance and Pension Funds Supervisory Authority, 2017. Statistics on the Car Insurance by District. Available at http://www.asf.com.pt/NR/exeres/7D383D469431-416E-98C7-395B0A9E7080.htm (Accessed on January 3rd). .

Jaganmohan, M., Knapp, S., Buchmann, C.M., Schwarz, N., 2016. The bigger, the better? The influence of urban green space design on cooling effects for residential areas. J. Environ. Qual. 45 (1), 134-145.

Janhäll, S., 2015. Review on urban vegetation and particle air pollution - deposition and dispersion. Atmos. Environ. 305, 130-137.

Kabisch, N., Strohbach, M., Haase, D., Kronenberg, J., 2016. Urban green space availability in European cities. Ecol. Indic. 70, 586-596.

Kanniah, K., 2017. Quantifying green cover change for sustainable urban planning: A case of Kuala Lumpur, Malaysia. Urban For. Urban Green. 27, 287-304.

Li, W., Saphores, J., Gillespie, T., 2015. A comparison of the economic benefits of urban green spaces estimated with NDVI and with high-resolution land cover data. Landsc. Urban Plan. 133, 105-117.

Liu, J., Wang, Y., Kang, J., Yu, T., Zimmer, C., 2017. Factors associated with soundscape experiences in urban green spaces: a case study in Rostock, Germany. Urban For. Urban Green. https://doi.org/10.1016/j.ufug.2017.11.003.

Lo, A., Byrne, J., Jim, C., 2017. How climate change perception is reshaping attitudes towards the functional benefits of urban trees and green space: lessons from Hong Kong. Urban For. Urban Green. 23, 74-83.

Macit, M., Gümrükçüoğlu, M., 2012. Determination of industrial sulfur dioxide emissions and mapping by geographic information system. Polish J. Environ. Stud. 21 (3), 549-558.

MG - Municipality of Guimarães, 2015. Master Municipal Plan of Guimarães. Diário da República, $2^{\mathrm{a}}$ série 119, 16682-16706 (in Portuguese).

MG - Municipality of Guimarães, 2018. Candidacy to the European Capital Award 2020. Available at: https://cm-guimaraes.pt (Accessed at March 1st). .

Molnár, P., Stockfelt, L., Barregard, L., Sallsten, G., 2015. Residential NOx exposure in a 35 -year cohort study. Changes of exposure, and comparison with back extrapolation for historical exposure assessment. Atmos. Environ. 115, 62-69.

Muttoo, S., Ramsay, L., Brunekreef, B., Beelen, R., Meliefste, K., Naidoo, R., 2018. Land use regression modelling estimating nitrogen oxides exposure in industrial south Durban, South Africa. Sci. Total Environ. 610-611, 1439-1447.

Nowak, D., Hirabayashi, S., Doyle, M., McGovern, M., Pasher, J., 2017. Air pollution removal by urban forests in Canada and its effect on air quality and human health. Urban For. Urban Green. https://doi.org/10.1016/j.ufug.2017.10.019.

NPRCDC - North Portugal Regional Coordination and Development Commission, 2014. Regional Inventory on Atmospheric Emissions. Available at http://www.ccdr-n.pt/ sites/default/files/ficheiros_ccdrn/ambiente/inventario emissoes rn.pdf (in Portuguese). Accessed on September $\left.16^{\text {th }}\right)$. .

Oliveira, S., Vaz, T., Andrade, H., 2014. Perception of thermal comfort by users of urban green areas in Lisbon. Finisterra 98, 113-131.

Paas, B., Schneider, C., 2016. A comparison of model performance between ENVI-met and Austal2000 for particulate matter. Atmos. Environ. 145, 392-404.

Parente, J., Pereira, M., Tonini, M., 2016. Space-time clustering analysis of wildfires: the influence of dataset characteristics, fire prevention policy decisions, weather and climate. Sci. Total Environ. 559, 151-165.

Parvez, F., Wagstrom, K., 2018. Comparing estimates from the R-LINE near road dispersion model using model-derived and observation-derived meteorology. Atmos. 
Pollut. Res. 9, 483-493.

Pasquier, A., André, M., 2017. Considering criteria related to spatial variabilities for the assessment of air pollution from traffic. Transp. Res. Procedia 25, 3354-3369.

PEA-Portuguese Environment Agency, 2015. Portuguese National Inventory Report on Greenhouse Gases. APA, Amadora (in Portuguese).

PEA-Portuguese Environment Agency, 2016. Available at: https://apambiente.pt (accessed at May 2nd).

PEA-Portuguese Environmental Agency, 2017. QualAr - Online Database on Air Quality (in Portuguese). Available at: https://qualar.apambiente.pt/qualar (Accessed at March 1st). .

Rojas, C., Páez, A., Barbosa, O., Carrasco, J., 2016. Accessibility to urban green spaces in Chilean cities using adaptive thresholds. J. Transp. Geogr. 57, 227-240.

Sahu, S., Patra, A., Kolluru, S., 2018. Spatial and temporal variation of respirable particles around a surface coal mine in India. Atmos. Pollut. Res. 9, 662-679.

Sanches, P., Pellegrino, P., 2016. Greening potential of derelict and vacant lands in urban areas. Urban For. Urban Green. 19, 128-139.

Schäffler, A., Swilling, M., 2013. Valuing green infrastructure in an urban environment under pressure, the Johannesburg case. Ecol. Econ. 86, 246-257.

Schebella, M., Weber, D., Schultz, L., Weinstein, P., 2019. The wellbeing benefits associated with perceived and measured biodiversity in Australian urban green spaces. Sustainability 11,802

Seinfeld, J., Pandis, S., 2006. Atmospheric Chemistry and Physics: From Air Pollution to Climate Change, second edition. Wiley, New Jersey.

Selmi, W., Weber, C., Rivière, E., Blond, N., Mehdi, L., Nowak, D., 2016. Air pollution removal by trees in public green spaces in Strasbourg city, France. Urban For. Urban Green. 17, 192-201.

Setälä, H., Viippola, V., Rantalainen, A., Pennanen, A., Yli-Pelkonen, V., 2013. Does urban vegetation mitigate air pollution in northern conditions? Environ. Pollut. 183, 104-112.

Shahbazi, H., Taghvaee, S., Hosseini, V., Afshin, H., 2016. A GIS based emission inventory development for Tehran. Urban Clim. 17, 216-229.

Silva, L., Pinho, J., Nurusman, H., 2014. Traffic air pollution monitoring based on an airwater pollutants deposition device. Int. J. Environ. Sci. Technol. 11 (8), 2307-2318.

Silva, L., 2015. Environmental quality health index for cities. Habitat Int. 45 (1), 29-35.

Silva, L., Mendes, J., 2012. City noise-air: an environmental quality index for cities. Sustain. Cities Soc. 4, 1-11.

Slezakova, K., Castro, D., Begonha, A., Delerue-Matos, C., Alvim-Ferraz, M., Morais, S., Pereira, M., 2011. Air pollution from traffic emissions in Oporto, Portugal: health and environmental implications. Microchem. J. 99, 51-59.

SP - Statistics Portugal, 2012. 15th Housing and Population Census. INE., Lisbon.
Su, J., Apte, J., Lipsitt, J., Garcia-Gonzales, D., Beckerman, B., Nazelle, A., Texcalac Sangrador, J., Jerrett, M., 2015. Populations potentially exposed to traffic-related air pollution in seven world cities. Environ. Int. 78, 82-89.

Subba, J., Thammakhet, C., Thavarungkul, P., Kanatharana, P., 2016. Distributions of $\mathrm{SO} 2$ and NO2 in the lower atmosphere of an industrial area in Bhutan. J. Environ. Sci. Health Part A 0, 1-10.

Tan, S., Shi, G., Wang, H., 2012. Long-range transport of spring dust storms in Inner Mongolia and impact on the China seas. Atmos. Environ. 46, 299-308.

Tian, Y., Jim, C., Wang, H., 2014. Assessing the landscape and ecological quality of urban green spaces in a compact city. Landsc. Urban Plan. 121, 97-108.

Tong, Z., Whitlow, T., MacRae, P., Landers, A., Harada, Y., 2015. Quantifying the effect of vegetation on near-road air quality using bief campaigns. Environ. Pollut. 201, 141-149.

Tunno, B., Shields, K., Cambal, L., Tripathy, S., Holguin, F., Lioy, P., Clougherty, J., 2015. Indoor air sampling for fine particulate matter and black carbon in industrial communities in Pittsburgh. Sci. Total Environ. 536, 108-115.

Van Renterghem, T., Botteldooren, D., Verheyen, K., 2012. Road traffic noise shielding by vegetation belts of limited depth. J. Sound Vib. 331, 2404-2425.

Vos, P., Maiheu, B., Vankerkom, J., Janssen, S., 2013. Improving local air quality in cities: To tree or not to tree? Environ. Pollut. 183, 113-122.

Wang, H., Schneider, W., 2011. Adsorption and reactions of NOx on RuO2(110). Catal. Today 165, 49-55.

Wang, Z., Wang, S., Xu, Q., Ho, T., 2016. Impacts of flare emissions from an ethylene plant shutdown to regional air quality. Atmos. Environ. 138, 22-41.

Whitlow, T., Pataki, D., Alberti, M., Pincetl, S., Setälä, H., Cadenasso, M., Felson, A. McComas, K., 2014. Comments on "modeled PM2.5 removal by trees in ten U.S. cities and associated health effects" by Nowak et al. (2013). Environ. Pollut. 191, 256.

Wolch, J., Byrne, J., Newell, J., 2014. Urban green space public health, and environmental justice: the challenge of making cities 'just green enough'. Landsc. Urban Plan. 125, 234-244.

Wolf, K., Cyrys, J., Harciníková, T., Gu, J., Kusch, T., Hampel, R., Schneider, A., Peters, A., 2017. Land use regression modeling of ultrafine particles, ozone, nitrogen oxides and markers of particulate matter pollution in Augsburg, Germany. Sci. Total Environ. 579, 1531-1540.

Zannin, P., Ferreira, A., Szeremetta, B., 2006. Evaluation of noise pollution in urban parks. Environ. Monit. Assess. 118, 423-433.

Zhang, K., Batterman, S., 2013. Air pollution and health risks due to vehicle traffic. Sci. Total Environ. 450-451, 307-316.

Zhou, X., Rana, M., 2012. Social benefits of urban green space: a conceptual framework of valuation and accessibility measurements. Manag. Environ. Qual. Int. J. 23, 173-189. 